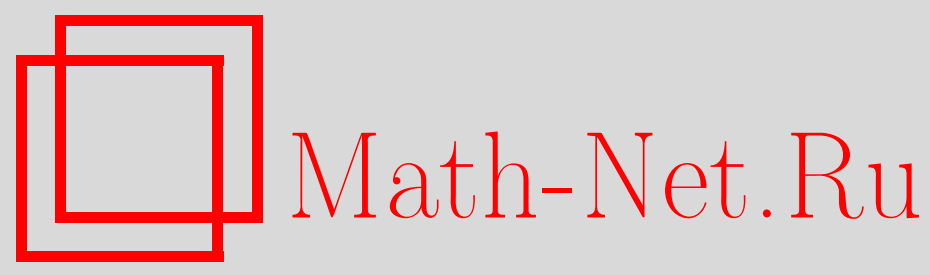

K 80-летию Григория Ивановича Ивченко, Матем. вопр. криптогр., 2020, том 11, выпуск 1, 5-7

DOI: https://doi.org/10.4213/mvk311

Использование Общероссийского математического портала Math-Net.Ru подразумевает, что вы прочитали и согласны с пользовательским соглашением http://www.mathnet.ru/rus/agreement

Параметры загрузки:

IP : 54.237 .59 .107

26 апреля 2023 г., 16:37:50

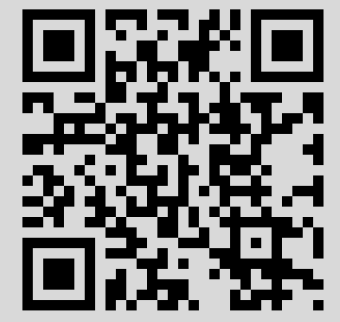




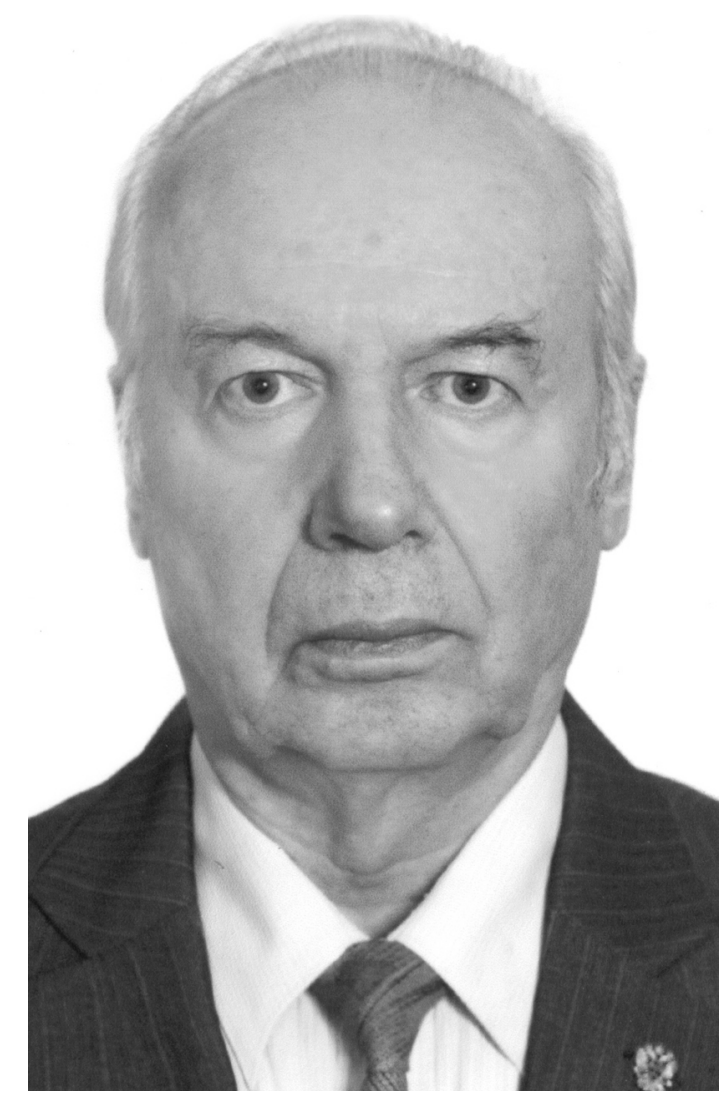

\section{К 80-летию Григория Ивановича Ивченко}

2 января 2020 года исполнилось 80 лет со дня рождения Григория Ивановича Ивченко, видного отечественного математика-криптографа, доктора физико-математических наук, профессора, действительного члена Академии криптографии Российской Федерации.

Г.И. Ивченко после окончания в 1962 году механикоматематического факультета МГУ имени М.В. Ломоносова по распределению был направлен на работу в подразделение Специальной службы. С 1971 года по 2012 год заведовал кафедрой теории вероятностей и математической статистики в Московском государственном институте электроники и математики (ныне входящем в Высшую школу экономики). В 1973 году в совете МИЭМ защитил докторскую диссертацию по теоретико-вероятностным методам криптографии. В 1974 году Г.И. Ивченко присвоено ученое звание профессора. В июне 
1994 года он был избран членом-корреспондентом Академии криптографии Российской Федерации, а в 2002 году - ее действительным членом. С 2016 года работает в Академии криптографии Российской Федерации в должности главного научного сотрудника.

Во время работы в Спецслужбе Г.И. Ивченко занимался вопросами анализа и синтеза криптографических систем. Полученные им результаты отражены в 20 научных работах. Параллельно с преподавательской деятельностью Григорий Иванович работал по совместительству в 1972-1987 годах в НИИ автоматики Министерства радиопромышленности СССР, занимаясь теоретико-вероятностными и статистическими проблемами анализа спецаппаратуры. Г.И. Ивченко был одним из организаторов Проблемной научно-исследовательской лаборатории дискретной математики в МИЭМ, а также ее руководителем в течение ряда лет.

Г.И. Ивченко - известный специалист в области теории вероятностей, математической статистики, комбинаторного анализа и теоретической криптографии. Он автор более 200 научных трудов, бо́льшая часть которых непосредственно связана с тематикой спецслужб. Его основные научные результаты относятся к разработке общих методов исследования широкого класса вероятностных моделей, предельных теорем для различных типов статистик и случайных процессов в рамках этих моделей, а именно к разработке статистических критериев и статистических методов оценивания и исследованию их эффективности. Им получены важные результаты по случайным отображениям, графам, подстановкам, разбиениям конечных множеств, многочленам над конечными полями, спектральному анализу случайных булевых функций.

На основе этих исследований им опубликовано (лично и в соавторстве) значительное число научных работ, в том числе более 10 монографий и учебных пособий. В частности, в соавторстве с Ю.И. Медведевым подготовлены и изданы книги «Дискретные распределения. Вероятностно-статистический справочник. Одномерные распределения» (2015 г.) и «Многомерные распределения» (2016 г.). В 2020 году планируется публикация монографии «Дискретные вероятностные модели».

Многие годы Григорий Иванович посвятил преподавательской деятельности и подготовке научных кадров. Он подготовил и читал лекции и оригинальные спецкурсы в МИЭМ и Академии ФСБ России. Более 10 его учеников защитили кандидатские диссертации и один - 
докторскую. Им написаны в соавторстве ряд учебников и учебных пособий по специальности «Прикладная математика» для вузов, среди которых «Математическая статистика», «Теория вероятностей и математическая статистика в задачах», «Введение в математическую статистику», «Задачи с решениями по математической статистике» и др.; эти книги неоднократно переиздавались, а некоторые переведены на иностранные языки.

Григорий Иванович в течение многих лет активно участвует в работе Временных проблемных комиссий Академии криптографии Российской Федерации. При его участии и под его непосредственным руководством проведен ряд фундаментальных и прикладных исследований. Он является членом редколлегий академических журналов «Дискретная математика» и «Математические вопросы криптографии».

За успешную научную, педагогическую и общественную работу Григорий Иванович в 1986 году награжден Орденом Трудового Красного Знамени; неоднократно награждался руководством министерств и ведомств, в которых он работал.

Поздравляя Григория Ивановича с 80-летием, желаем ему доброго здоровья, оптимизма, активной жизненной позиции и новых творческих успехов в научной деятельности.

Редакционная коллегия 2020, T. 11, № 1 , C. 5-7 
